\title{
Digestive proteolytic activity in Apodiphus amygdali Germar (Hemiptera: Pentatomidae): effect of endogenous inhibitors
}

\author{
S. Ramzi, A. Zibaee \\ Department of Plant Protection, University of Guilan, Rasht, Iran
}

\begin{abstract}
The digestive proteolytic profile of Apodiphus amygdali was determined by using several substrates and specific inhibitors. Analysis of optimal $\mathrm{pH}$ and temperature showed the highest enzymatic activity at the $\mathrm{pH}$ range of 6-7 and temperature of $40^{\circ} \mathrm{C}$ when azocasein was used as a substrate. By using a negative control, the presence of several specific proteases were determined including tryspin-like, chymotrypsinlike, elastase, cathepsin B, cathepsin L, amino- and carboxypeptidases in the midgut content of $A$. amygdali, with the highest and the lowest activities of cathepsin $\mathrm{L}$ and carboxypeptidase, respectively. $\mathrm{pH}$ dependency of specific proteases revealed optimal pHs of 9,8 and 9 for trypsin-, chymotrypsin-like, 6 for cathepsins and 5-6 for carboxy- and aminopeptidases, respectively. Specific inhibitors, including phenylmethylsulfonyl fluoride, Na-p-tosyl-L-lysine chloromethyl ketone, $\mathrm{N}$ tosyl-L-phenylalanine chloromethyl ketone, L-trans-epoxysuccinylleucylamido-(4-guanidino)-butane, phenanthroline and ethylendiamidetetraacetic acid, significantly decreased proteolytic activity, indicating the presence of different proteases in the midgut of $A$. amygdali. Extracted inhibitors from the midgut demonstrated significant inhibition of specific proteolytic activities of $A$. amygdali except for cathep$\sin B$ and aminopeptidase. The results indicated that determination of digestive proteolytic activity could be helpful to clarify digestion
\end{abstract}

Correspondence: Arash Zibaee, Department of Plant Protection, Faculty of Agricultural Sciences, University of Guilan, Rasht, 416351314, Iran.

Tel.: +98.0131.6690274 - Fax: +98.0131.6690281.

E-mail: arash.zibaee@gmx.com ; arash.zibaee@guilan.ac.ir

Key words: Apodiphus amygdali, digestive protease, inhibitor.

Acknowledgements: the authors want to thank Dr. Ali Sarafrazi from Iranian Institute of Plant Protection for his contribution in identification of collected insects.

Received for publication: 7 August 2013.

Revision received: 19 November 2013.

Accepted for publication: 19 November 2013.

(C) Copyright S. Ramzi and A. Zibaee, 2014

Licensee PAGEPress, Italy

Journal of Entomological and Acarological Research 2014; 46:1868

doi:10.4081/jear.2014.1868

This article is distributed under the terms of the Creative Commons Attribution Noncommercial License (by-nc 3.0) which permits any noncommercial use, distribution, and reproduction in any medium, provided the original author(s) and source are credited. process in insects. Moreover, understanding the nature of digestive proteases might be used to develop several inhibitors for providing resistant crop varieties against pests.

\section{Introduction}

Apodiphus amygdali Germar (Hemiptera: Pentatomidae) is a polyphagous and univoltine hemipteran distributed throughout Europe and the Middle East (Schuh \& Slater 1995). It feeds on several fruit trees, especially plum, apricot, apple, olive, pear and pistachio as well as non-fruit trees like poplar, pine, plane-tree, elm and willow bark (Muhammed \& Al-Iraqi, 2010). Nymphs and adults feed on leaves, fruits and flowers by injecting their salivary secretions into the plant tissues to liquefy nutrient materials. Feeding on stems and fruits causes host weakness and attracts other insects to feed on host plants. Feeding on fruits is the primary damage and causes complete degradation and yield loss (Schuh \& Slater, 1995).

Digestive proteases are one of the crucial enzymes in the alimentary canals of insects since proteins are the key nutrients for growth, development and reproduction (Nation, 2008). The enzymes are classified based on their activity against protein molecules. In fact, proteases that attack internal bonds are called endopeptidases (proteinases) but exopeptidases refers to proteases separating amino acids from $\mathrm{N}$ - and C-terminal of proteins, known as aminopeptidases (EC 3.4.11.2) and carboxypeptidases (EC 3.4.11.7) (Terra \& Ferreira, 2012). Endopeptidases are divided into different subclasses based on their $\mathrm{pH}$ dependency and catalytic sites. Serine proteases, including trypsin- (EC 3.4.21.4), chymotrypsin-like (EC 3.4.21.1) and elastase (EC 3.4.21.36), are active in alkaline $\mathrm{pH}$ and they have serine, histidine, and aspartic acid residues in their catalytic sites (Terra \& Ferreira, 2012). Meanwhile, these enzymes have different structural features that are associated with their different substrate specificities (Terra \& Ferreira, 2012). Cysteine proteases are active at acidic $\mathrm{pH}$, including cathepsins B (EC 3.4.22.1) and L (EC 3.4.22.15). Cathepsin L (EC 3.4.22.15) is a true endopeptidase that preferentially cleaves peptide bonds in $\mathrm{P}_{2}$ against the hydrophobic amino acid residues, but cathepsin B prefers arginine at the same position (Barrett et al., 1998). Digestion of proteins is initiated by endopeptidases; due to the activity of endopeptidases, oligopeptidases are attacked from the $\mathrm{N}$ and C-terminal by amino- and carboxypeptidases, resulting in dipeptides that are hydrolyzed by dipeptidases (Terra \& Ferreira, 2012).

Since synthetic chemicals cause severe negative effects on the environment, non-target organisms and induce resistance in pests, numerous studies have been conducted on the use of biocontrol agents and digestive enzyme inhibitors against agricultural pests. Enzymatic inhibitors disrupt digestion process of insects and nutrient absorption, thereby decreasing reproduction and therefore pest populations. Protease inhibitors are small proteins that are present in up to 100 plant 
species and they are effective on serine and cysteine proteases (Nation, 2008). Although this approach may be suitable for decreasing economic losses caused by pests with the least environmental disruption, comprehensive experiments are required to achieve the final goal. Determination of proteolytic profiles and their properties are the first and fundamental step in this approach. The objectives of the current study were to determine digestive proteolytic profiles in A. amygdali, the effect of synthetic inhibitors, and to extract endogenous inhibitors.

\section{Materials and methods}

\section{Insect rearing}

Fifth nymphal instars of A. amygdali were collected from elm trees in Shiraz (Fars province, Iran) and transferred to the laboratory. The nymphs were reared on elm leaves at $28 \pm 1^{\circ} \mathrm{C}, 70 \%$ relative humidity and a 16L:8D of photoperiod. When adults emerged, they were allowed to feed on leaves for $48 \mathrm{~h}$ prior to being randomly selected for biochemical analysis.

\section{Sample preparation}

Based on the method of Cohen (1993), adults of A. amygdali were randomly selected and their midgut removed by dissection in iced saline solution $(\mathrm{NaCl}, 10 \mathrm{mM}, 1.06404 .1000$, Merck-Chemicals, Darmstadt, Germany). Integument and unneeded organs were removed and the midgut was gently separated and rinsed in $1 \mathrm{~mL}$ of iced distilled water. To obtain appropriate samples, five midguts were placed in one Eppendorff tube (Eppendorff, Hamburg, Germany) containing $1 \mathrm{~mL}$ of distilled water. Tissues were ground using a homogenizer and centrifuged at 13,000 rpm for $20 \mathrm{~min}$ at $4^{\circ} \mathrm{C}$ (Daika, Rika Kugyo Co., Tokyo, Japan). The supernatant was carefully removed, transferred to new tubes and stored at $-20^{\circ} \mathrm{C}$ for no more than one week until use in the experiments.

\section{General proteolytic assay}

Azocasein (2\%; A2765; Sigma-Aldrich Co., St. Louis, M0, USA) was used to find the general proteolytic activity in the midgut of $A$. amygdali adults. General proteolytic activity was measured by using azocasein $2 \%$ based on the method of Elpidina et al. (2001). The reaction mixture consisted of $50 \mu \mathrm{L}$ of appropriate buffer solutions (Universal buffer, $0.02 \mathrm{M}$, containing succinate, glycine and 2-morpholinoethanesulfonic acid; pH range 3-12; Frugoni, 1957), $20 \mu \mathrm{L}$ azocasein and $20 \mu \mathrm{L}$ of the enzyme solution. After incubation at $37^{\circ} \mathrm{C}$ for $60 \mathrm{~min}$, proteolysis was stopped by adding $100 \mu \mathrm{L}$ of $30 \%$ trichloroacetic acid (TCA). Precipitation was achieved by cooling at $4{ }^{\circ} \mathrm{C}$ for $10 \mathrm{~min}$; it was then centrifuged at 13,000 rpm for another $10 \mathrm{~min}$. An equal volume of $2 \mathrm{M}$ $\mathrm{NaOH}$ was added to the supernatant and the absorbance was recorded at $450 \mathrm{~nm}$ (Awareness Technology Inc., Palm City, FL, USA). A blank solution consisted of all the above-mentioned portions except the for enzyme solution.

\section{Optimal pH and temperature $\left({ }^{\circ} \mathrm{C}\right)$ for general proteolytic activity}

The reaction mixture was the same as described above, but different $\mathrm{pH}$ ranges of universal buffer (from 3 to 12) and temperature (from 20 to $70^{\circ} \mathrm{C}$ ) were used to determine optimal $\mathrm{pH}$ and temperature. For the optimal $\mathrm{pH}$ assays, $40 \mu \mathrm{L}$ of buffer solution (at different $\mathrm{pHs}$ ) was incubated with azocasein as a substrate for $10 \mathrm{~min}$ at $30^{\circ} \mathrm{C}$ (Terra \& Ferreira, 2012). Then, $20 \mu \mathrm{L}$ of sample was added and the experiment continued as above. For the optimal temperature assays, $40 \mu \mathrm{L}$ of buffer solution (at the optimal $\mathrm{pH}$ found) was incubated with azocasein as a substrate for $10 \mathrm{~min}$ at different temperature regimes from 20 to $70^{\circ} \mathrm{C}$.
After adding $20 \mu \mathrm{L}$ of the sample, the reaction mixture was incubated at each given temperature for $60 \mathrm{~min}$. Other steps were conducted as described above.

\section{Specific protease assays}

\section{Serine proteases}

Trypsin-, chymotrypsin- and elastase-like activities (as three subclasses of serine proteases) were assayed using a $1 \mathrm{mM}$ concentration of BApNA (Nabenzoyl-L-arginine-p-nitroanilide, Sigma-Aldrich, 19362), 1 mM SAAPPpNA (N-succinyl-alanine-alanine-proline-phenylalanine-p-nitroanilide, Sigma-Adrich, S7388) and $1 \mathrm{mM}$ SAAApNA (N-succinyl-alanine-alanine-alanine-p-nitroanilide, Sigma-Aldrich, S4760) as substrates, respectively. The reaction mixture consisted of $35 \mu \mathrm{L}$ of universal buffer ( $\mathrm{pH} 8$, as the recommended $\mathrm{pH}$ for serines in the literature), $5 \mu \mathrm{L}$ of each substrate, and $5 \mu \mathrm{L}$ of enzyme solution. The reaction mixture was incubated at $30^{\circ} \mathrm{C}$ for a period of $0-10$ min before adding 30\% TCA to terminate the reaction. The absorbance of the resulting mixture was then measured spectrophotometrically at $405 \mathrm{~nm}$ by $p$-nitroaniline release. To prove the specific proteolytic activity, a negative control for each substrate was provided separately containing all the above components except for enzyme pre-boiled at $100^{\circ} \mathrm{C}$ for $30 \mathrm{~min}$ (Oppert et al., 1997).

\section{Cysteine proteases}

Cathepsins B and L activities (as three subclasses of cysteine proteases) were assayed using a $1 \mathrm{mM}$ concentration of Z-Ala-Arg-Arg 4methoxy- $\beta$-naphtylamide acetate (Sigma-Aldrich, C8536) and $\mathrm{N}$ Benzoyl-Phe-Val-Arg-p-nitroanilide hydrochloride (Sigma-Aldrich, B2133) as substrates, respectively. The reaction mixture consisted of $35 \mu \mathrm{L}$ of universal buffer ( $\mathrm{pH} 5$ as the recommended $\mathrm{pH}$ for cysteines in the literature), $5 \mu \mathrm{L}$ of each substrate and $5 \mu \mathrm{L}$ of enzyme solution. The reaction mixture was incubated at $30^{\circ} \mathrm{C}$ for a period from $0-10 \mathrm{~min}$ before adding 30\% TCA to terminate the reaction and read at $405 \mathrm{~nm}$. To prove the specific proteolytic activity, a negative control for each substrate was provided separately containing all the above components except for enzyme pre-boiled at $100^{\circ} \mathrm{C}$ for $30 \mathrm{~min}$ (Oppert et al., 1997).

\section{Exopeptidases}

The activities of two exopeptidases were obtained by using HippurylL-Arginine (Sigma-Aldrich, H2508) and Hippuryl-L-Phenilalanine (Sigma-Aldrich, H6875) for amino- and carboxypeptidases in the midgut of $A$. spinidens. The reaction mixture consisted of $35 \mu \mathrm{L}$ of universal buffer $(\mathrm{pH} 7$ as the recommended $\mathrm{pH}$ in the literature for exopeptidases), $5 \mu \mathrm{L}$ of each substrate and $5 \mu \mathrm{L}$ of enzyme solution. The reaction mixture was incubated at $30^{\circ} \mathrm{C}$ for a period from $0-10 \mathrm{~min}$ before adding 30\% TCA to terminate the reaction and read at $340 \mathrm{~nm}$. To prove the specific proteolytic activity, a negative control for each substrate was provided separately containing all the above components except for enzyme pre-boiled at $100^{\circ} \mathrm{C}$ for $30 \mathrm{~min}$ (Oppert et al., 1997).

\section{Optimal pH determination of specific proteases}

Universal buffer was used to find the optimal pH of serine and cysteine proteases in addition to exopeptidases by using the specific substrates described. The reaction mixture and experiment procedure were the same as above.

\section{Effect of specific inhibitors on proteolytic activity}

The following compounds were used to find any alteration of the proteolytic activity in the midgut of $A$. spinidens: phenylmethylsulfonyl fluoride (PMSF) (Sigma-Aldrich, P7626); trypsin inhibitor, Na-p-tosyl-Llysine chloromethyl ketone (TLCK) (Sigma-Aldrich, T5012); chymotrypsin inhibitor, N-tosyl-L-phenylalanine chloromethyl ketone 
(TPCK) (Sigma-Aldrich, T7254); cysteine protease inhibitor, L-transepoxysuccinyl-leucylamido-(4-guanidino)-butane (E-64) (Sigmaaldrich, E3132); cystatin (Sigma-Aldrich, C8917), metalloprotease inhibitors including phenanthroline (Sigma-Aldrich, 131377) and ethylendiamidetetraacetic acid (EDTA) (Merck-Chemicals).

\section{Extraction of endogenous inhibitors}

Endogenous inhibitors from the midgut of A. amygdali were extracted by the method of Lwalaba et al. (2010) with slight modifications. Midguts of adults $(\mathrm{N}=10)$ were incubated in $500 \mu \mathrm{L}$ of low glucose Ringer's solution (121.5 mM NaCl; $10 \mathrm{mM} \mathrm{KCl} ; 2.1 \mathrm{mM} \mathrm{NaH}_{2} \mathrm{PO}_{4} ; 10$ $\mathrm{mM} \mathrm{NaHCO}{ }_{3} ; 0.7 \mathrm{mM} \mathrm{MgCl} ; 2.2 \mathrm{mM} \mathrm{CaCl}_{2} ; \mathrm{pH}=6.8$ and 0.01 g glucose) for $30 \mathrm{~min}$ at $30^{\circ} \mathrm{C}$. The tissues were then ground using a glass homogenizer. These samples taken from different species were heated to $90^{\circ} \mathrm{C}$ for $30 \mathrm{~min}$. Samples were centrifuged at $13,000 \mathrm{rpm}$ for $20 \mathrm{~min}$ at $4^{\circ} \mathrm{C}$. The obtained supernatants were used as the source of inhibitors.

\section{Effect of endogenous inhibitors on specific proteolytic activity}

The reaction mixture contained $50 \mu \mathrm{L}$ of universal buffer, $20 \mu \mathrm{L}$ of each substrate and $20 \mu \mathrm{L}$ of endogenous inhibitor. After 5 min of incubation, $10 \mu \mathrm{L}$ of the enzyme was added and proteolytic activity was read at $405 \mathrm{~nm}$ after $10 \mathrm{~min}$. A blank contained all components except the enzyme.

\section{Protein assay}

Protein concentration was measured according to the method of Lowry et al. (1951). In this method, peptide bonds are oxidized by FolinCiocalteu reagent. Briefly, $20 \mu \mathrm{L}$ of sample was added to $100 \mu \mathrm{L}$ of reagent, which was incubated for $30 \mathrm{~min}$ prior to reading the absorbance at $545 \mathrm{~nm}$ (Recommended by Ziest Chem. Co., Tehran, Iran).

\section{Statistical analysis}

The experimental design was based on a completely randomized design and Tukey's test was used to compare treatment means. Statistical differences were considered at $\mathrm{P} \leq 0.05$. Results from the synthetic inhibitors trials were analyzed using POLO-PC software to calculate inhibitory concentration (IC) values.

\section{Results}

\section{Optimal pH and temperature of general proteolytic activity}

Determination of the optimal $\mathrm{pH}$ for general proteolytic activity resulted in two peaks in the acid and alkaline ranges. The larger peak was observed at the $\mathrm{pH}$ range of 6-7 and the smaller peak was found at the $\mathrm{pH}$ range of 9-10 (Figure $1 \mathrm{~A} ; \mathrm{F}=40.99, \mathrm{Pr}<\mathrm{F}$ : 0.0001). General proteolytic activity increased at temperatures from $25-40^{\circ} \mathrm{C}$ with the highest value at $40^{\circ} \mathrm{C}$, and then sharply decreased at $45-60^{\circ} \mathrm{C}$ (Figure $1 \mathrm{~B}$; $\mathrm{F}=32.81, \operatorname{Pr}<\mathrm{F}: 0.0001$ ).

\section{Determination of specific proteases present}

Activities of trypsin-, chymotrypsin-like, elastase, cathepsin B, L, amino- and carboxypeptidases were confirmed by using boiled midgut homogenate as a negative control (Figure 2). Chymotrypsin showed the highest activity among serine proteases and cathepsin L and aminopeptidase had the highest activity among cysteine proteases and exopeptidases, respectively ( $\mathrm{F}=31.78, \operatorname{Pr}<\mathrm{F}$ : 0.0001). Taken collectively, the highest and the lowest enzymatic activities were observed for cathepsin L and carboxypeptidase, respectively (Figure 2; F=31.78, $\operatorname{Pr}<$ F: 0.0001).

\section{Optimal pH determination of specific proteases}

Figures 3-5 demonstrate the $\mathrm{pH}$ dependency of proteases with specific substrates. The highest activity of trypsin-like protease was found at a pH range of 7-9, with the highest activity at $\mathrm{pH} 9$ (Figure $3 ; \mathrm{F}=27.53$, $\mathrm{Pr}<\mathrm{F}$ : 0.0001). Chymotrypsin-like and elastase proteases had the highest activity at $\mathrm{pHs}$ of 8 and 9, respectively (Figure 3B and $\mathrm{C} ; \mathrm{F}=9.21$, $\operatorname{Pr}<F$ : 0.0001; F=10.95, $\operatorname{Pr}<F: 0.0001)$. The highest activity of cathepsin $\mathrm{B}$ was obtained at $\mathrm{pH} 6$ (Figure 4; F=17.17, $\mathrm{Pr}<\mathrm{F}$ : 0.0001) but cathepsin $\mathrm{L}$ showed the highest activity at a pH range of 4-6 (Figure 4; $\mathrm{F}=17.75$,
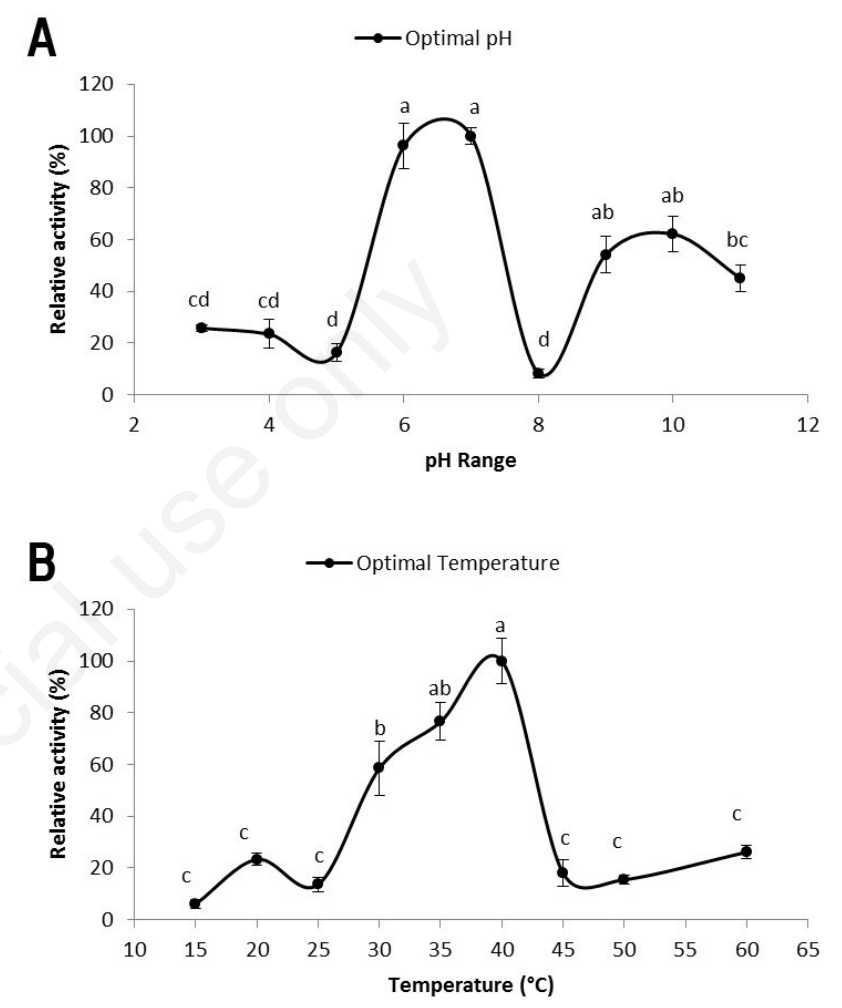

Figure 1. Optimal $\mathrm{pH}(\mathrm{A})$ and temperature (B) for general proteolytic activity in the midgut of $A$. amygdali. Letters show statistical differences among values (Tukey's test, $\mathbf{P} \leq \mathbf{0 . 0 5}$ ).

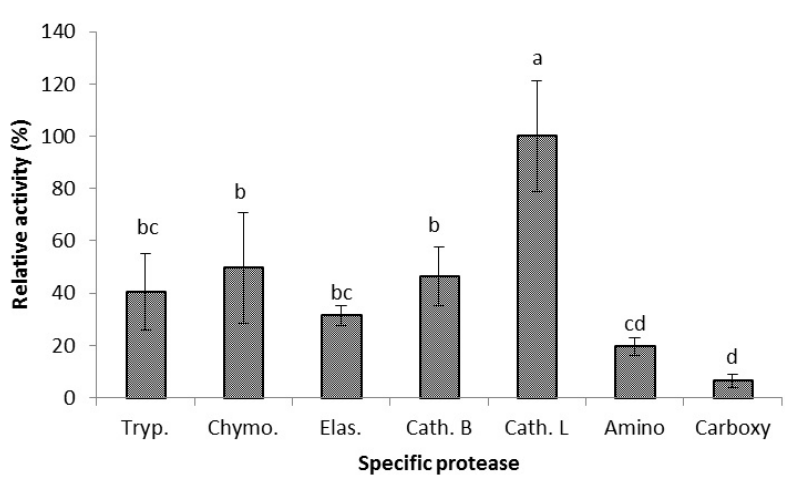

Figure 2. Presence of specific proteases in the midgut of $A$. amygdali by using specific substrates and negative control. Letters show statistical differences among values (Tukey's test, $\mathrm{P} \leq \mathbf{0 . 0 5}$ ). 
$\operatorname{Pr}<$ F: 0.0001). Amino- and carboxypeptidases showed the highest activity at pHs of 6 and 5, respectively, although there was a slight non-statistical difference between these values for aminopeptidase (Figure $5 \mathrm{~A}$ and B; F=28.08, $\operatorname{Pr}<F$ : 0.0001; F=20.34, $\operatorname{Pr}<F$ : 0.0001).

\section{Effect of synthetic and endogenous inhibitors on proteolytic activity}

PMSF, TLCK and TPCK, as specific inhibitors of serines, trypsin and chymotrypsin proteases, significantly decreased proteolytic activity in the midgut of $A$. amygdali (Figure 6A; $\operatorname{Pr}<\mathrm{F}$ : 0.0001, $\mathrm{F}=1547.84 ; \operatorname{Pr}<\mathrm{F}$ : 0.0001, $\mathrm{F}=16.83 ; \operatorname{Pr}<\mathrm{F}: 0.0001, \mathrm{~F}=54.56)$. Among these inhibitors, PMSF had the most significant effect on proteolytic activity, with the result that the enzymatic activity sharply decreased to lower than 20\% (Figure 6A; $\operatorname{Pr}<\mathrm{F}$ : 0.0001, F=1547.84). Proteolytic activity in the midgut of A. amygdali was significantly affected by cystatin and E-64, with cystatin decreasing the enzymatic activity to lower than 5\% (Figure 6B; $\mathrm{Pr}<\mathrm{F}$ : 0.0001 ,
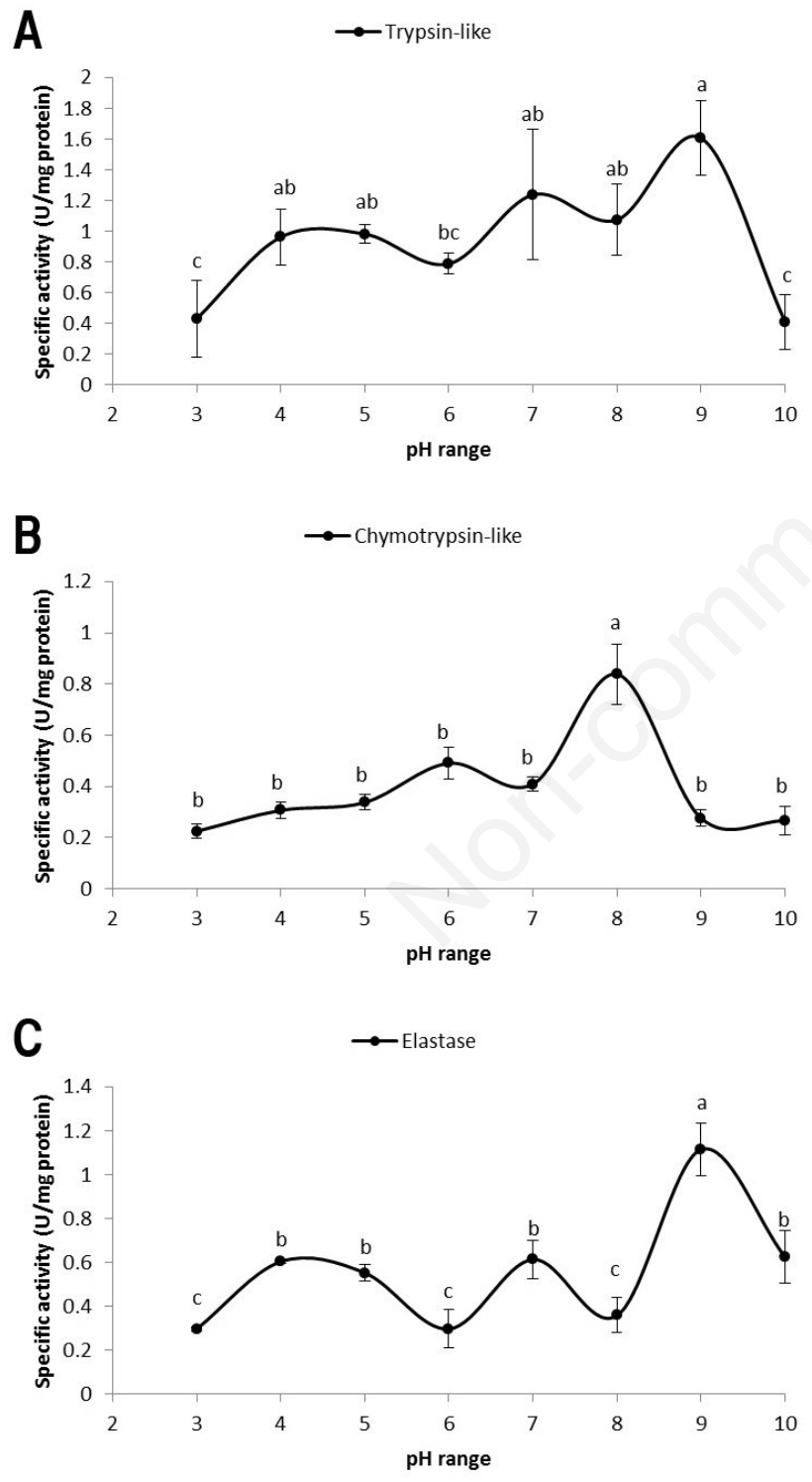

Figure 3. Optimal $\mathrm{pH}$ for serine proteases (A-C) in the midgut of $A$. amygdali. Letters show statistical differences among values (Tukey's test, $\mathbf{P} \leq 0.05$ ).
F=74.76; $\operatorname{Pr}<F: 0.0001, F=54.36 ; \operatorname{Pr}<F: 0.0001, F=68.44)$. Phenanthroline and EDTA also significantly decreased proteolytic activity to $20 \%$ (Figure 6C; $\operatorname{Pr}<$ F: 0.0001, F=25.58; Pr<F: 0.0001, F=48.75). Table 1 shows IC values of the above mentioned inhibitors in which PMSF had the lowest $\mathrm{IC}_{50}$ on proteolytic activity, while TLCK, phenanthroline and EDTA had the highest value. Extracted inhibitor from the midgut of $A$. amygdali significantly decreased specific proteolytic activity except for cathepsin B and aminopeptidase (Table 2; F=35.64, Pr>F: 0.0001).

\section{Discussion and conclusions}

A critical role of proteases could be expected in the midgut of $A$. amygdali, as this is a polyphagous hemipteran that feeds on different trees. In the current study, several proteases were found in the midgut, although cysteine proteases, mainly cathepsin L, showed the highest activity among the proteases assayed. Results of other studies partially correspond with our findings. Stamopoulos et al. (1993) and Bell et al. (2005) demonstrated trace activities of trypsin and chymotrypsin in the gut of Podisus maculiventris Say (Hemiptera: Pentatomidae). Silva \& Terra (1994) reported the presence of cysteine proteases in the midgut of Dysdercus peruvianus Guérin-Méneville (Hemiptera: Pyrrhocoridae). Pascual-Ruiz et al. (2009) reported serine, cysteine, aminopeptidase and carboxypeptidase as the main proteases involved in protein digestion of $P$. maculiventris, although their activities can differ due to variability of prey. Zhu et al. (2003) and Wright et al. (2006) found high activities of cysteine and serine proteases in the midgut of Lygus lineolaris and $L$. Hesperus Knight (Hemiptera: Miridae). Bigham \& Hosseininaveh (2010) found the presence of cathepsins B and L in the

A

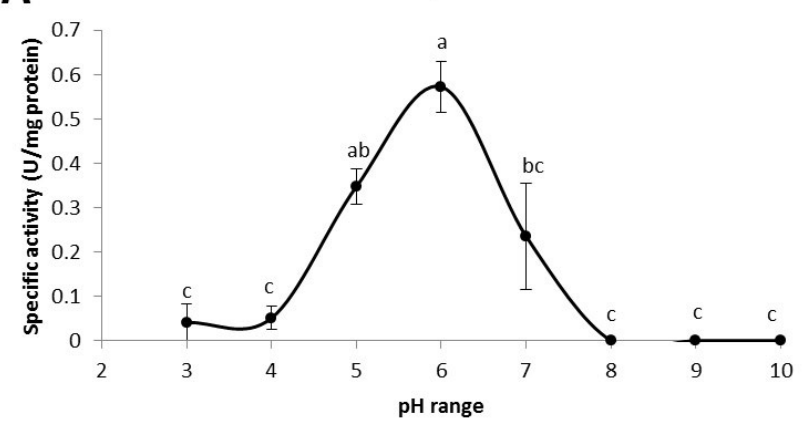

B

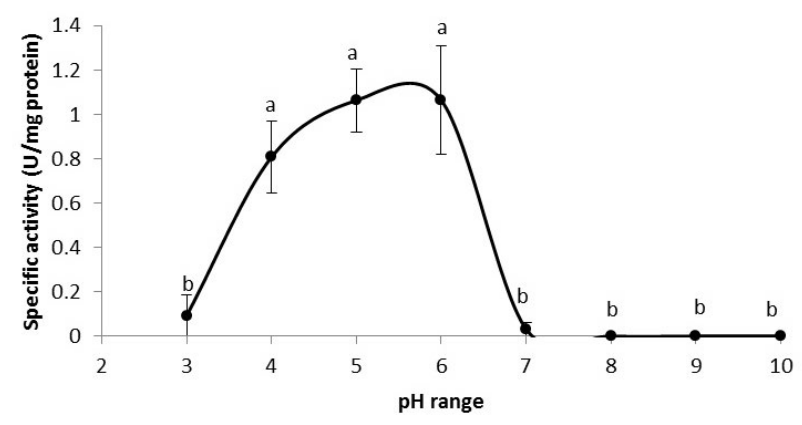

Figure 4. Optimal $\mathrm{pH}$ for cysteine proteases (A and $\mathrm{B}$ ) in the midgut of $A$. amygdali. Letters show statistical differences among values (Tukey's test, $\mathbf{P} \leq \mathbf{0 . 0 5}$ ). 
midgut of Brachynema germari Kolenati (Hemiptera: Pentatomidae). Fialho et al. (2012) obtained cathepsin L and aminopeptidase as the major proteases from the midgut of Podisus nigrispinus Dallas (Hemiptera: Pentatomidae). Sorkhabi-Abdolmaleki et al. (2013) reported both serine and cysteine proteases through the significant role of cysteines in the midgut content of Andrallus spinidens Fabricius (Hemiptera: Pentatomidae).

The optimal $\mathrm{pH}$ for general proteolytic activity in the midgut of $A$. amygdali was represented as two peaks at both acidic and alkaline $\mathrm{pHs}$, indicating the presence of all the determined proteases (see above). Zhu et al. (2003) found optimal proteolytic activity of Lygus lineolaris Knight (Hemiptera: Miridae) at $\mathrm{pH} 4.25$ and 8.5. Wright et al. (2006) found acidic and neutral pHs for caseinolytic activity in $L$. lineolarius that might be attributed to cysteine and serine proteases. Bigham \& Hosseininaveh (2010) observed the presence of general protease activity by acidic and alkaline optima in the midgut extract of $B$. germari using hemoglobin as a substrate. Sorkhabi-Abdolmaleki et al. (2013) found an alkaline $\mathrm{pH}$ for general proteolytic activity, serine proteases and two exopeptidases with another peak at $\mathrm{pH} 6$, as with the cysteine proteases. The optimal $\mathrm{pH}$ of specific proteases corresponds with the expected values, as noted in the literature (Terra \& Ferreira, 2012). A pH peak was observed for all specific proteases except for cathepsin L, for which the enzyme was active at a $\mathrm{pH}$ range of 4-6. This could be attributed to the presence of several isozymes and higher activity of cathepsin L. Variations in optimal pH of general proteolytic activity in insects could be attributed to feeding habits as either monophagous or polyphagous. Since polyphagous insects feed on various hosts, the presence of different proteases and the difference in general protease $\mathrm{pH}$ could be attributed to host materials or secondary metabolites of plants.

An optimal temperature of $40^{\circ} \mathrm{C}$ was found for general proteolytic

A

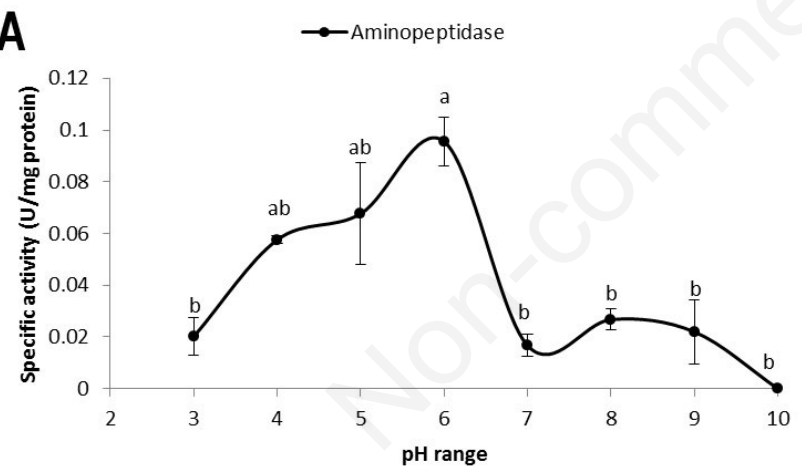

B

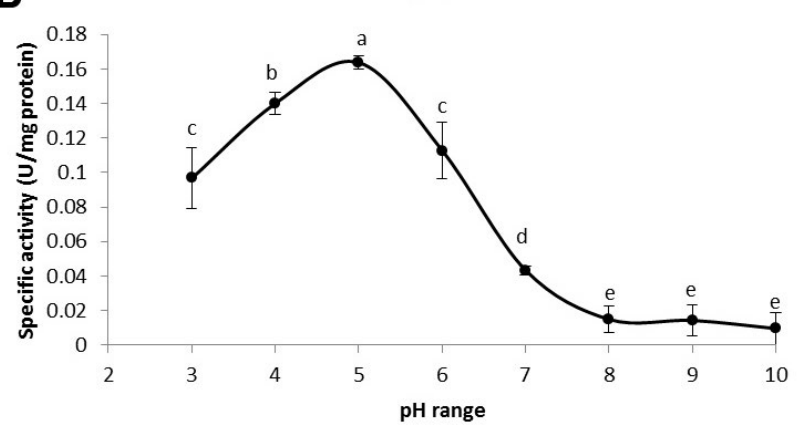

Figure 5. Optimal $\mathrm{pH}$ for exopeptidases (A and $\mathrm{B})$ in the midgut of $A$. amygdali. Letters show statistical differences among values (Tukey's test, $\mathrm{P} \leq 0.05$ ). activity, although there was slightly lower but not statistically different activity at $35^{\circ} \mathrm{C}$. Generally, optimal temperature of an enzyme in in vitro assays reflects the temperature of the environment where the organism feeds on its hosts. Increasing temperature can disrupt hydrogen bonds in the three-dimensional structure of the molecule, leading to denaturation of the protein (Zeng et al., 2000). At the same time, biological reactions occur faster with increasing temperature, up to the point of enzyme denaturation, where the enzymatic activity and the rate of the reaction decrease sharply (Zeng et al., 2000). Swart et al. (2006) found $37^{\circ} \mathrm{C}$ as the optimal temperature for proteolytic activity in the salivary secretion of two belostomatid bugs. Sorkhabi-Abdolmaleki
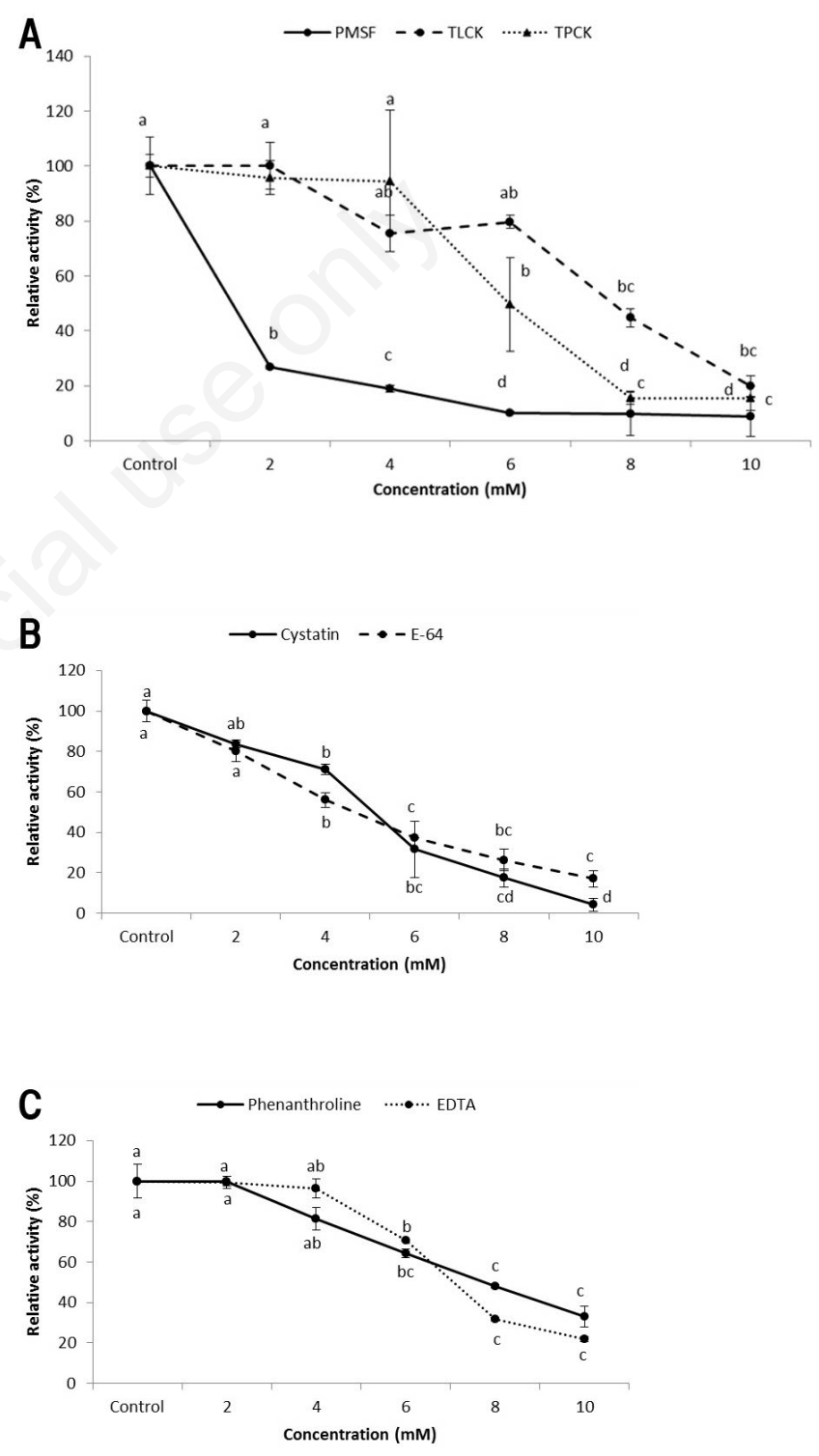

Figure 6. Effect of specific inhibitors on general proteolytic activity in the midgut of $A$. amygdali. A) Specific inhibitors of serine proteases; B) Specific inhibitors of cysteine proteases; C) Specific inhibitors of metalloproteinase. Letters show statistical differences among values (Tukey's test, $\mathrm{P} \leq \mathbf{0 . 0 5}$ ). PMSF, phenylmethylsulfonyl fluoride; TLCK, Na-p-tosyl-L-lysine chloromethyl ketone; TPCK, N-tosyl-L-phenylalanine chloromethyl ketone; $\mathrm{E}$ 64, L-trans-epoxysuccinyl-leucylamido-(4-guanidino)-butane; EDTA, ethylendiamidetetraacetic acid. 
\& Zibaee (2013) reported an optimal temperature of $25^{\circ} \mathrm{C}$ for proteolytic activity in the midgut of $A$. spinidens that corresponded with laboratory conditions of mass-rearing.

Our results demonstrated inhibitory effects of PMSF, TLCK and TPCK on the proteolytic activity in the midgut of $A$. amygdali. PMSF showed the highest inhibition of enzymatic activity with the lowest $\mathrm{IC}_{50}$ value $(0.574$ $\mathrm{mM}$ ), in comparison with TLCK (7.13) and TPCK (5.19). These results corresponded with previous results on the presence of serine proteinases, especially chymotryptic activities, in the midgut of $A$. amygdali, which have been supported by using a negative control and specific substrates. Zhu et al. (2003) found serine proteases as the major enzymes in the gut of $L$. lineolaris by TLCK (Zhu et al., 2003). Bigham \& Hosseininaveh (2010) and Sorkhabi et al. (2013) found significant inhibition of digestive proteases by PMSF, TLCK and TPCK in $B$. germary and $A$. spinidens. Presence of cysteine proteases was confirmed by using specific substrates, cystatin, E-64 and DTT, although the experiment with a negative control showed cathepsin $\mathrm{L}$ as the major protease in the midgut of $A$. amygdali. Houseman and Dowe (1983) found cathepsin B and L activities in the posterior midgut of Rodnius prolixus L. (Hemiptera: Reduviidae). Overney et al. (1997) reported cysteines as the major proteases in the midgut of Perillus bioculatus Fabricius (Hemiptera: Pentatomidae), showing inhibition of $90 \%$ by E- 64 . Proteolytic activity in the midgut of $L$. lineolaris was significantly decreased with E-64 (Wright et al., 2006). Bigham \& Hosseininaveh (2010) found negative effects of E-64 on the proteolytic activity of A. spinidens. Sorkhabi-Abdolmaleki et $a l$. (2013) observed that E-64 and cystatin decreased proteolytic activity in the midgut of $A$. spinidens.

EDTA as general chelating agent and phenanthroline as metalloproteinase inhibitor significantly decreased proteolytic activity in the midgut of $A$. amygdali, indicating the presence of metal ions in the active sites of aminopeptidase. Aminopeptidases are divided into aminopeptidase $\mathrm{A}$ and $\mathrm{N}$ based on the presence of $\mathrm{Zn}^{2+}$ and $\mathrm{Mn}^{2+}$ in their active sites (Terra \& Ferreira, 2012). There is little knowledge on the characterization of aminopeptidases' active site. Ferreira \& Terra (1986) employed multiple inhibition analysis to find the possible role of EDTA on inactivation of aminopeptidase in Rhynchosciara americana Wideman (Diptera: Sciaridae) larvae. The authors found two sub- sites in the active center of the enzyme: a hydrophobic subsite to which isoamyl alcohol binds, exposing the metal ion, and a polar subsite, to which hydroxylamine binds (Ferreira \& Terra, 1986). Exposure of the metal ion after isoamyl alcohol binding may be analogous to the situation when a part of the substrate occupies the hydrophobic subsite to cause conformational changes associated with the catalytic step (Ferreira \& Terra, 1986). Cristofoletti \& Terra (2000) found that the catalysis property of aminopeptidase in Tenebrio molitor L. (Coleoptera: Tenebrionidae) depends on a metal ion, a carboxylate and a protonated imidazole group. Detailed experiments revealed that the enzyme is a zinc metallopeptidase like mammalian aminopeptidase $\mathrm{N}$, but it differs in some details (Cristofoletti \& Terra, 2000).

Extraction of endogenous inhibitors from the midgut of $A$. amygdali revealed diverse effects on specific proteolytic activities. In serine proteases, inhibition was more significant in the case of trypsin and elastase than chymotrypsin. In the case of cysteine and exopeptidases, cathepsin B and aminopeptidase were not affected by the endogenous inhibitor. Endogenous inhibitors may have several functions, such as protection of $\alpha$-amylase from proteolytic activity (Stein \& Fischer, 1958), attacking fungi and bacteria in gut (Taranushenko et al., 2009) and protection of epithelial cells from digestive enzymes when food is not present in the midgut (Lwalaba et al., 2010). Engelmann \& Geraert (1980) reported extraction of the midgut lumen content in Leucophaea madera Fabricius (Blattodea: Oxyhaloidae) as an endogenous inhibitor. Lwalaba et al. (2010) extracted an endogenous inhibitor from the midgut of Spodoptera frugiperda Hubner (Lepidoptera: Noctuidae) larvae. It was found that the ability of the endogenous inhibitor to decrease trypsin activity was similar to the results from ingestion of the exogenous inhibitor SBTI. Zibaee et al. (2012) and Sorkhabi-Abdolmaleki et al. (2013) extracted endogenous inhibitors from Chilo suppressalis Walker (Lepidoptera: Crambidae), Naranga aenescens Moore (Lepidoptera: Noctuidae), Pieris brassicae L. (Lepidoptera: Pieridae), Hyphantria cunea Drury (Lepidoptera: Arctiidae) and Ephestia kuhniella Zeller (Lepidoptera: Pyralidae). The authors found different effects of inhibitors on salivary and midgut proteases of $A$. spinidens (Zibaee $e t$ al., 2012; Sorkhabi-Abdolmaleki \& Zibaee, 2013). Specifically, extracted inhibitors from $C$. suppressalis, $N$. aenescens and E. kuehniella signifi-

Table 1. Determination of inhibitory concentrations $(\mathrm{mM})$ of specific inhibitors on proteolytic activity in the midgut of $A$. amygdali.

\begin{tabular}{lccccc} 
Compound & $I_{10}$ & $I_{30}$ & $I_{50}$ & Slope \pm SF & $\chi^{2}$ \\
PMSF & $0.045^{\mathrm{e}}$ & $0.574^{\mathrm{f}}$ & $0.574^{\mathrm{e}}$ & $1.16 \pm 0.27$ & 0.568 \\
TLCK & $3.57^{\mathrm{b}}$ & $5.38^{\mathrm{a}}$ & $7.13^{\mathrm{ab}}$ & $4.27 \pm 0.40$ & 25.27 \\
\hline TPCK & $3.2^{\mathrm{b}}$ & $4.65^{\mathrm{b}}$ & $5.91^{\mathrm{b}}$ & $5.04 \pm 0.39$ & 37.46 \\
Cystatin & $1.99^{\mathrm{c}}$ & $3.18^{\mathrm{c}}$ & $4.41^{\mathrm{c}}$ & $3.71 \pm 0.29$ & 17.44 \\
\hline E-64 & $1.39^{\mathrm{cd}}$ & $2.75^{\mathrm{cd}}$ & $4.41^{\mathrm{c}}$ & $2.55 \pm 0.25$ & 0.293 \\
DTT & $0.59^{\mathrm{d}}$ & $1.56^{\mathrm{e}}$ & $3.07^{\mathrm{d}}$ & $1.79 \pm 0.24$ & 39.21 \\
\hline Phenanthroline & $3.44^{\mathrm{b}}$ & $5.43^{\mathrm{a}}$ & $7.46^{\mathrm{a}}$ & $3.81 \pm 0.38$ & 2.79 \\
EDTA & $4.33^{\mathrm{a}}$ & $5.80^{\mathrm{a}}$ & $7.10^{\mathrm{ab}}$ & $5.95 \pm 0.52$ & 21.49 \\
\hline
\end{tabular}

IC, inhibitory concentrations; PMSF, phenylmethylsulfonyl fluoride; TLCK, Na-p-tosyl-L-lysine chloromethyl ketone; TPCK, N-tosyl-L-phenylalanine chloromethyl ketone; E-64, L-trans-epoxysuccinyl-leucylamido-(4guanidino)-butane; DDT, dithiothreitol; EDTA, ethylendiamidetetraacetic acid. a,b,c,d,e,f́Ltters show statistical differences among values (Tukey's test, P $\leq 0.05$ ).

Table 2. Effect of endogenous inhibitor on specific proteolytic activity in the midgut of $A$. amygdali.

\begin{tabular}{|c|c|c|c|c|c|c|c|}
\hline & Tryspin & Chymotrypsin & Elastase & Cathepsin B & Cathepsin L & Aminopetidase & Carboxypeptidase \\
\hline Control & $1.59 \pm 0.02^{*}$ & $0.82 \pm 0.01^{*}$ & $1.10 \pm 0.11^{*}$ & $0.55 \pm 0.05$ & $1.04 \pm 0.024^{*}$ & $0.094 \pm 0.009$ & $0.16 \pm 0.003^{*}$ \\
\hline Treatment & $0.15 \pm 0.025$ & $0.23 \pm 0.06$ & $0.046 \pm 0.003$ & $0.65 \pm 0.05$ & $0.015 \pm 0.012$ & $0.17 \pm 0.001^{*}$ & $0.024 \pm 0.001$ \\
\hline
\end{tabular}

*Asterisks show statistical differences among values (Student's $\mathrm{t}$-test, $\mathrm{P} \leq 0.05$ ). 
cantly decreased trypsin and chymotrypsin activities. All extracted inhibitors significantly decreased elastase and cathepsin activities of $A$. spinidens except for $C$. suppressslis (Sorkhabi-Abdolmaleki \& Zibaee, 2013). Extracted inhibitors from all species significantly decreased cathepsins B and L activities, but this decrease was not significantly different in the case of $C$. suppressalis. In the case of exopeptidases, endogenous inhibitors from $E$. kuehniella and $H$. cunea on aminopeptidase and all inhibitors on carboxypeptidase significantly decreased enzymatic activities (Sorkhabi-Abdolmaleki \& Zibaee, 2013).

In conclusion, the presence of different specific proteases involved in protein digestion was found in A. amygdali using specific substrates and inhibitors. These enzymes had different $\mathrm{pH}$ profiles and extracted endogenous inhibitors from the insect's midgut significantly decreased the majority of the proteases. These results were expected, as A. amygdali feeds on several host plants. Sometimes, A. amygdali is used as a rearing host for Trissolcus spp. parasitoids (a biocontrol agent of wheat sunn pest), so these findings could be helpful for efficient mass-rearing. A. amygdali occasionally occurs as a secondary pest of agricultural products, so the possible use of protease inhibitors could be a promising method to avoid the use of pesticide sprays.

\section{References}

BARRETT A.J., RAWLINGS N.D., WASNER J.F., 1998 - Handbook of proteolytic enzymes. -Academic Press, London.

BELL H.A., DOWN R.E., EDWARDS J.P., GATEHOUSE J.A., ANGHARD M.R., GATEHOUSE M.R., 2005- Digestive proteolytic activity in the gut and salivary glands of the predatory bug Podisus maculiventris (Heteroptera: Pentatomidae); effect of proteinase inhibitors. Euro. J. Entomol. 102: 139-145.

BIGHAM M., HOSSEININAVEH V., 2010 - Digestive proteolytic activity in the pistachio green stink bug, Brachynema germari Kolenati (Hemiptera: Pentatomidae). - J. Asia-Pacific. Entomol. 13: 221-227.

COHEN A.C., 1993 - Organization of digestion and preliminary characterization of salivary trypsin like enzymes in a predaceous Heteropteran, Zelus renadii. - J. Insect. Physiol. 39: 823-829.

CRISTOFOLETTI P.T., TERRA W.R., 2000 - The role of amino acid residues in the active site of a midgut microvillar aminopeptidase from the beetle Tenebrio molitor. - Biochim. Biophys. Acta. 1479: 185-195.

ELPIDINA E.N., VINOKUROV K.S., GROMENKO V.A., RUDENSKAYA Y.A., DUNAEVSKY Y.E., ZHUZHIKOV D.P., 2001 - Compartmentalization of proteinases and amylases in Nauphoeta cinerea midgut. - Arch. Insect. Biochem. Physiol. 48: 206-216.

ENGELMANN F., GERAERTS W.P.M., 1980 - The proteases and the protease inhibitors in the midgut of Leucophaea maderae. - J. Insect. Physiol. 26: 703-710.

FERREIRA C., TERRA W.R., 1986 - Substrate specificity and binding loci for inhibitors in an aminopeptidase purified from the plasma membrane of midgut cells of an insect (Rhynchosciara americana) larva. - Arch. Biochem. Biophys. 244: 478-485.

FIALHO M.C.Q., MOREIRA N.R., ZANUNCIO J.C., RIBEIRO A.F., TERRA W.R., SERRÃO J.E., 2012 - Prey digestion in the midgut of the predatory bug Podisus nigrispinus (Hemiptera: Pentatomidae). - J. Insect. Physiol. 58: 850-856.

FRUGONI J.A.C., 1957 - Tampone universale di Britton e Robinson a forza ionica costante. - Gazz. Chim. Ital. 87: 403-407.

LOWRY 0.H., ROSENBROUGH N.J., FARR A.L., RANDALL R.J., 1951 -
Protein measurement with the Folin phenol reagent. - J. Biol. Chem. 193: 265-75.

LWALABA D., WEIDLICH S., HOFFMANN K.H., WOODRING J., 2010 Exogenous and endogenous protease inhibitors in the gut of the fall armyworm larvae, Spodoptera frugiperda. - Arch. Insect. Biochem. Physiol. 74: 114-126.

MUHAMMED S.H., AL-IRAQI R.A., 2010 - The biology of the stink bug Apodiphus amygdali Germar (Hemiptera: Pentatomidae). - Mesopotamia J. Agric. 38: 1-11.

NATION J.L., 2008 - Insect physiology and biochemistry. 2nd ed. - CRC press, Boca Raton, FL: 544.

OPPERT B., KRAMER K.J., MCGAUGHEY W.H., 1997 - Rapid microplate assay of proteinase mixtures. - Biotechnol. 23: 70-72.

OVERNEY S., FAWE A., YELLE S., MICHAUD D., 1997. - Diet-related plasticity of the digestive proteolytic system in larvae of the Colorado potato beetle (Leptinotarsa decemlineata Say). - Arch. Insect Biochem. Physiol. 36: 241-250.

PASCUAL-RUIZ S., CARRILO L., ALVAREZ-ALFAGEME F., RUIZ M., CASTANERA P., ORTEG0 F., 2009 - The effects of different prey regimes on the proteolytic digestion of nymphs of the spined soldier bug, Podisus maculiventris (Hemiptera: Pentatomidae). - Bull. Entomol. Res. 99: 487-491.

SCHUH R.T., SLATER J.A., 1995 - True bugs of the world. - Cornell University Press, Ithaca, NY: 336.

SORKHABI-ABDOLMALEKI, S., ZIBAEE A., 2013 - Role of endogenous inhibitors on digestive amylolytic and proteolytic activities of a predatory hemipteran, Andrallus spinidens Fabricius. - Arch. Phystopathol. Plant. Protec. [In press].

SORKHABI-ABDOLMALEKI S., ZIBAEE A., HODA H., HOSSEINI R., FAZELI-DINAN M., 2013 - Proteolytic compartmentalization and activity in the midgut of Andrallus spinidens Fabricius (Hemiptera: Pentatomidae). - J. Entomol. Acarol. Res. 45: 33-41.

STAMOPOULOS D.C., DIAMANTIDIS G., CHLORIDIS A., 1993 - Activités enzymatiques du tube digestif du prédateur Podisus maculiventris (Hemimptera: Pentatomidae). - Entomophaga. 38: 493-499.

STEIN E.A., FISCHER E.H., 1958 - The resistance of a-amylase towards proteolytic attack. - J. Biol. Chem. 232: 867-879.

SWART C.C., DEATON L.E., FELGENHAUER B.E., 2006 - The salivary gland and salivary enzymes of the giant waterbugs (Heteroptera; Belostomatidae). - Comp. Biochem. Physiol. Part A. 145: 114-122.

TARANUSHENKO Y., VINOKUROV K.S., KLUDKIEWICZ B., KODRIK D., SEHNAL F., 2009 - Peptide inhibitors from the salivary glands of the cockroach Nauphoeta cinerea. - Insect. Biochem. Mole. Biol. 39: 920-930.

TERRA W.R., FERRIERA C., 2012 - Biochemistry of digestion. In: GILBERT L.I. (Ed.), Insect molecular biology and biochemistry. Elsevier, Amsterdam: 365-418.

WRIGHT M.K., BRANDT S.L., COUDRON T.A., WAGNER R.M., HABIBI J., BACKUS E.A., HUESING J.E., 2006 - Characterization of digestive proteolytic activity in Lygus hesperus Knight (Hemiptera: Miridae). - J. Insect. Physiol. 52: 717-728.

ZENG F., COHEN A.C., 2000 - Partial characterization of $\alpha$-amylase in the salivary glands of Lygus hesperus and L. lineolaris. - Comp. Biochem. Physiol. Part B. 126: 9-16.

ZHU Y.C., ZENG F., OPPERT B., 2003 - Molecular cloning of trypsin-like cDNAs and comparison of proteinase activities in the salivary glands and gut of the tarnished plant bug Lygus lineolaris (Heteroptera: Miridae). - Insect. Biochem. Mol. Biol. 33: 889-899.

ZIBAEE A., HODA H., FAZELI-DINAN M., 2012 - Role of proteases in extra-oral digestion of a predatory bug, Andrallus spinidens. - J. Insect. Sci. 12: 51. 